\title{
Chronic Hypocalcemia of Vitamin D Deficiency Leads to Lower Intracellular Calcium Concentrations in Rat Hepatocytes
}

\author{
Marielle Gascon-Barré, ${ }^{\star *}$ Pierre Haddad, ${ }^{\ddagger}$ Sébastien J. Provencher, ${ }^{\star \star}$ Sylvain Bilodeau, ${ }^{* \neq}$ \\ Françoise Pecker,' Sophie Lotersztajn," and Sylvie Vallières" \\ ${ }^{*}$ Centre de Recherche Clinique André-Viallet, Hôpital Saint-Luc, and ${ }^{\ddagger}$ Département de Pharmacologie, Faculté de médecine, Université \\ de Montréal, Montreal, Canada H2X 1P1; and Institut National de la Santé et de la Recherche Médicale (INSERM) U99, Creteil, France
}

\section{Abstract}

Several lines of evidence indicate that calcium deficiency is associated with cellular defects in many tissues and organs. Owing to the large in vivo gradient between ionized extra- and intracellular $\mathrm{Ca}^{2+}$ concentrations $\left(\left[\mathrm{Ca}^{2+}\right]\right)$, it is generally recognized that the prevailing circulating $\mathrm{Ca}^{2+}$ does not significantly affect resting cytosolic $\mathrm{Ca}^{2+}$. To probe the consequences of hypocalcemia on $\left[\mathrm{Ca}^{2+}\right]_{i}$, a model of chronic hypocalcemia secondary to vitamin D (D) deficiency was used. Hepatocytes were isolated from livers of hypocalcemic D-deficient, of normocalcemic $D_{\mathbf{3}}$-repleted, or of normal control rats presenting serum $\mathrm{Ca}^{2+}$ of $0.78 \pm 0.02,1.24 \pm 0.03$, or $1.25 \pm 0.01 \mathrm{mM}$, respectively $(P<0.0001) .\left[\mathrm{Ca}^{2+}\right]_{\mathrm{i}}$ was measured in cell couplets using the fluorescent probe Fura-2. Hepatocytes of normocalcemic $D_{3}$ repleted and of normal controls exhibited similar $\left[\mathrm{Ca}^{2+}\right]_{i}$ of $227 \pm 10$ and $242 \pm 9 \mathrm{nM}$, respectively (NS), whereas those of hypocalcemic rats had significantly lower resting $\left[\mathrm{Ca}^{2+}\right]_{i}$ $(172 \pm 10 \mathrm{nM} ; P<0.0003)$. Stimulation of hepatocytes with the $\alpha_{1}$-adrenoreceptor agonist phenylephrine ilicited increases in cytosolic $\mathrm{Ca}^{2+}$ leading to similar $\left[\mathrm{Ca}^{2+}\right]_{1}$ and phosphorylase $a$ (a $\mathrm{Ca}^{2+}$-dependent enzyme) activity in all groups but in contrast to normocalcemia, low extracellular $\mathrm{Ca}^{2+}$ was often accompanied by a rapid decay in the sustained phase of the $\left[\mathrm{Ca}^{2+}\right]_{1}$ response. When stimulated with the powerful hepatic mitogen epidermal growth factor (EGF), hepatocytes isolated from hypocalcemic rat livers responded with a blunted maximal $\left[\mathrm{Ca}^{2+}\right]_{i}$ of 237.6 \pm 18.7 compared with $605.2 \pm 89.9 \mathrm{nM}(P<0.0001)$ for their normal counterparts, while the EGF-mediated DNA synthesis response was reduced by $50 \%$ by the hypocalcemic condition $(P<0.03)$. Further studies on the possible mechanisms involved in the perturbed $\left[\mathrm{Ca}^{2+}\right]$, homeostasis associated with chronic hypocalcemia revealed the presence of an unchanged plasma membrane $\mathrm{Ca}^{2+} \mathrm{ATPase}$ but of a significant decrease in agonist-stimulated $\mathrm{Ca}^{2+}$ entry as indicated using $\mathrm{Mn}^{2+}$ as surrogate ion $(P<0.03)$. Our data, thus indicate that, in rat hepatocytes, the in vivo calcium status significantly affects resting $\left[\mathrm{Ca}^{2+}\right]_{\text {, }}$ and from this we raise the hypothesis that this lower

Address correspondence to Dr. Marielle Gascon-Barré, Centre de Recherche Clinique André-Viallet, Hôpital Saint-Luc, 264 RenéLévesque Blvd. East, Montreal, Quebec, Canada H2X 1P1.

Received for publication 1 September 1993 and in revised form 17 December 1993.

J. Clin. Invest.

(C) The American Society for Clinical Investigation, Inc.

$0021-9738 / 94 / 05 / 2159 / 09 \$ 2.00$

Volume 93, May 1994, 2159-2167 than normal $\left[\mathrm{Ca}^{2+}\right]_{\mathrm{i}}$ may be linked, in calcium disorders, to inappropriate cell responses mediated through the calcium signaling pathway as illustrated by the response to phenylephrine and EGF. (J. Clin. Invest. 1994. 93:2159-2167.) Key words: calcium regulating hormones hepatocytes hypocalcemia intracellular calcium - receptor-operated calcium channelvitamin $\mathbf{D}_{\mathbf{3}}$

\section{Introduction}

In vivo, extracellular calcium homeostasis is under the control of three major hormones: PTH, calcitonin, and $1,25(\mathrm{OH})_{2} \mathrm{D}$, the hormone of the vitamin $D(D)^{1}$ endocrine system. Collectively these hormones interplay to maintain normal extracellular ionized calcium $\left(\mathrm{Ca}^{2+}\right)$ concentrations within the very narrow range of 1.15-1.35 mM. Circulating $\mathrm{Ca}^{2+}$ below 1.15 $\mathrm{mM}$ (hypocalcemia) or above $1.35 \mathrm{mM}$ (hypercalcemia) is sensed as abnormal and rapidly triggers reactive responses by the calcium regulating hormones leading to physiological adaptations in organs (intestine, kidney, bone) involved in the maintenance of calcium homeostasis. Moreover, chronic hypo- or hypercalcemia has been shown to lead to cellular defects in many tissues or organs. However, the mechanisms involved and the role played by the abnormal circulating calcium concentrations in the cellular pathophysiology of these defects have not yet been clearly identified.

At the cellular level, the response to many hormones and xenobiotics is transduced by changes in cytosolic calcium concentrations $\left(\left[\mathrm{Ca}^{2+}\right]_{i}\right)$ which first involves mobilization of intracellular pools but which is also often associated with entry of extracellular $\mathrm{Ca}^{2+}$ through plasma membrane channels $(1,2)$. Owing to the large in vivo concentration gradient between extra- and intracellular $\mathrm{Ca}^{2+}(\sim 10,000: 1)$, it is generally recognized, however, that the prevailing extracellular $\mathrm{Ca}^{2+}$ does not significantly affect $\left[\mathrm{Ca}^{2+}\right]_{i}$. Nevertheless, the observation that $D$ deficiency and/or hypocalcemia is linked with several disease states involving inadequate cellular responses prompted us to postulate that the prevailing circulating calcium might have a significant bearing on cellular events associated with signal transduction most particularly that associated with the calcium messenger system.

The aim of the present studies was, therefore, to investigate if the in vivo calcium status can significantly affect intracellular calcium homeostasis. This goal was achieved by studying the consequence of hypocalcemia on $\left[\mathrm{Ca}^{2+}\right]_{\mathrm{i}}$ in rat hepatocytes, a cell type known to be responsive to several agents acting through the calcium signaling pathway but having also the ad-

1. Abbreviation used in this paper. D; vitamin D. 
vantage of not being a direct target cell for the calcium regulating hormones. Using a model of chronic hypocalcemia secondary to $\mathrm{D}$ deficiency, we now report that both resting and stimulated $\left[\mathrm{Ca}^{2+}\right]_{\mathrm{i}}$ are sensitive to the endocrine calcium status as revealed by probing short-term primary culture of hepatocytes isolated from livers of rats either $(a)$ depleted in D thus presenting associated hypocalcemia, $(b)$ repleted in $D_{3}$ in order to normalize the $D$ endocrine status and hence calcium homeostasis, or $(c)$ from normal control rats.

\section{Methods}

\section{Animals}

To evaluate the influence of the circulating $\mathrm{Ca}^{2+}$ on $\left[\mathrm{Ca}^{2+}\right]_{i}$, animals were subjected to a functional calcium deprivation through $\mathrm{D}$ depletion as previously described (3). Briefly, nursing female Sprague-Dawley rats were fed a D-deficient diet starting at day 7 after parturition. At weaning, male rats were fed a D-deficient diet containing $0.9 \%$ elemental calcium (4) for 6-7 wk before being assigned to placebo or to $D_{3}$ repletion through intraperitoneal osmotic minipumps (Alza Corp., Palo Alto, CA) delivering $D_{3}$ at $6.5 \mathrm{nmol} / 24 \mathrm{~h} \times 7 \mathrm{~d}$. At the time of minipump implantation, a loading dose of $13 \mathrm{nmol} \mathrm{D}_{3}$ was administered to accelerate the establishment of steady state conditions. $D_{3}$-supplemented rats were given a $0.5 \%$ calcium gluconate solution as drinking water, whereas D-depleted animals received demineralized water. In addition to the two groups mentioned above, experiments were also carried out in normal rats fed a regular rat laboratory diet and regular tap water. All protocols were carried out in accordance with the standards of ethics for animal experimentation of the Canadian Council on Animal Care and were approved by the local animal ethics committee.

Concentrations of $\mathrm{Ca}^{2+}$ in blood, and in culture and experimental solutions were measured with a ICA2 ionized calcium analyzer (Radiometer, Copenhagen, Denmark).

\section{Isolation and primary culture of hepatocytes}

Hepatocytes were obtained from livers of nonfasting rats as previously described (5). The freshly isolated cells were then suspended in Krebs' buffer containing $1 \%$ albumin, $0.5 \mathrm{mM}$ glucose, sequentially filtered on $250-$ and $74-\mu \mathrm{m}$ filters, and centrifuged at $250 \mathrm{rpm}$ for $3 \mathrm{~min}$. The hepatocyte pellet was suspended as described above, and finally washed in culture medium taking care that extracellular $\mathrm{Ca}^{2+}\left(\left[\mathrm{Ca}^{2+}\right]_{e}\right)$ concentrations be as close as possible to that observed in vivo in eachanimal. Cell viability was evaluated by the Trypan blue exclusion test. Cell yield and viability were found to be identical in preparations from normal and D-deficient animals.

\section{Intracellular calcium homeostasis}

Resting and stimulated calcium measurement. Hepatocytes showing viability $90 \%$ were plated at a density of $3.5-5 \times 10^{5}$ cells $/ \mathrm{ml}$ onto collagen-coated coverslips (no. 1 circle, $22 \mathrm{~mm}$ diam) in Williams E medium containing $25 \mathrm{mM}$ bicarbonate, $1 \% \mathrm{BSA}$, and the appropriate $\left[\mathrm{Ca}^{2+}\right]_{e}$ for each experimental condition at $\mathrm{pH} 7.4,37^{\circ} \mathrm{C}$ in $5 \% \mathrm{CO}_{2}$ atmosphere. After incubation for $60 \mathrm{~min}$, cells were loaded for $30 \mathrm{~min}$ at $20^{\circ} \mathrm{C}$ with the fluorescent probe Fura-2 AM (2.5-3 $\left.\mu \mathrm{M}\right)$ (Molecular Probes, Inc., Eugene, OR) in bicarbonate-free Williams E medium supplemented with $2.5 \%$ FBS and $1 \%$ BSA. Dye-loaded cells were then transferred onto the stage of an inverted microscope (Nikon Diaphot, Nikon Corp., Tokyo, Japan) equipped for epifluorescence measurement. Coverslips formed the bottom of a specially designed plastic chamber $(100 \mu \mathrm{l})$ which was perfused with a $37^{\circ} \mathrm{C}$ Krebs-Henseleit solution equilibrated with $\mathrm{O}_{2} / \mathrm{CO}_{2}(95: 5$, vol:vol). Hepatocytes isolated from the different rat populations were found to adhere equally well to the collagen-coated coverslips and displayed identical gross morphological features in bright-field or phase-contrast microscopy. $\left[\mathrm{Ca}^{2+}\right]_{i}$ measurements were performed in hepatocyte couplets rather than in single cells because they provide a model where epithelial cell polarity is maintained and ion movements are tightly coupled (6).
Fluorescence signals from hepatocyte couplets were obtained with a SPEX model CM1T11I dual-excitation spectrofluorometer (Rayonics Scientific Inc., Saint-Laurent, Quebec). Excitation wavelengths were 350 and $380 \mathrm{~nm}$, and fluorescence emission was measured at $505 \mathrm{~nm}$ every $2 \mathrm{~s}$. To take into account the cellular microenvironment of the hepatocyte preparations, intracellular dye calibration was always performed in situ at the end of an experiment by perfusion of ionomycin $(10 \mu \mathrm{M})$ in a solutioncontaining $4 \mathrm{mM}$ EGTA $\left(R_{\min }\right)$, or $4 \mathrm{mM} \mathrm{CaCl}_{2}$ $\left(R_{\max }\right)$. After correction for sample autofluorescence, signal ratios $\left(F_{350} / F_{380}\right)$ were transformed into $\left[\mathrm{Ca}^{2+}\right]_{\mathrm{i}}(7)$, using the software supplied by SPEX. Autofluorescence, intracellular dye spectra and loading capacities were found to be equivalent in all groups, as illustrated in Fig. 1. The average signal-to-noise ratios measured at the isobestic point of $360 \mathrm{~nm}(8)$ were $9.92,9.46$, and 9.54 in hepatocytes of D-deficient, $D_{3}$-repleted, and normal rat livers, respectively. The presence of nonhydrolyzed dye was periodically verified by quenching with $2 \mathrm{mM}$ $\mathrm{MnCl}_{2}$ and found to be negligible when compared to autofluorescence.

$\left[\mathrm{Ca}^{2+}\right]_{\mathrm{i}}$ was measured in hepatocytes during resting conditions. In addition, studies were performed in order to investigate the possible consequences of hypocalcemia on agonist-mediated $\left[\mathrm{Ca}^{2+}\right]_{i}$ responses. Thus, hepatocytes were stimulated either with the calcium mobilizing agent phenylephrine, an $\alpha_{1}$-adrenoreceptor agonist, or with EGF, a growth factor known to ilicit increases in $\left[\mathrm{Ca}^{2+}\right]_{\mathrm{i}}$. Hepatocytes were perfused with phenylephrine or EGF (Sigma Chemical Co, St. Louis, $\mathrm{MO}$ ) at $37^{\circ} \mathrm{C}$ in $\mathrm{O}_{2} / \mathrm{CO}_{2}$ equilibrated $\mathrm{Krebs-Henseleit} \mathrm{buffer} \mathrm{at} \mathrm{saturat-}$ ing concentrations of $8 \mu \mathrm{M}$ or $8.2 \mathrm{nM}$, respectively.

Resting $\mathrm{Ca}^{2+}$ ATPase. To evaluate the activity of the cytosolic calcium pump, liver plasma membrane vesicles were prepared from frozen livers obtained from hypo- or normocalcemic rats according to Prpic et al. (9). The ATP-dependent $\mathrm{Ca}^{2+}$ transport activity was measured as previously described by Jouneaux et al. (10).

Agonist-stimulated calcium $\left(\mathrm{Mn}^{2+}\right)$ entry. In an attempt to elucidate the importance of extracellular $\mathrm{Ca}^{2+}$ ions in the $\left[\mathrm{Ca}^{2+}\right]_{i}$ response to agonists in extracellular conditions compatible with states of hypo- or normocalcemia in vivo, $500 \mu \mathrm{M}$ Mn was added to the perfusion buffer of Fura-2 AM-loaded hepatocytes obtained from hypo-andnormocalcemic rat livers. The $\mathrm{Mn}^{2+}$-mediated fluorescence quenching of the Fura-2 signal was then monitored at the excitation wavelengths of 334 and $360 \mathrm{~nm}$. The simultaneous and parallel loss of fluorescence observed at 334 and $360 \mathrm{~nm}$ was taken as an indicator of $\mathrm{Mn}^{2+}$ entry through receptor-operated, voltage-independent $\mathrm{Ca}^{2+}$ channel as already reported (2).

The cellular entry of $\mathrm{Mn}^{2+}$ mediated by $8 \mu \mathrm{M}$ phenylephrine, or 50 nM EGF application was evaluated by calculating the slopes induced

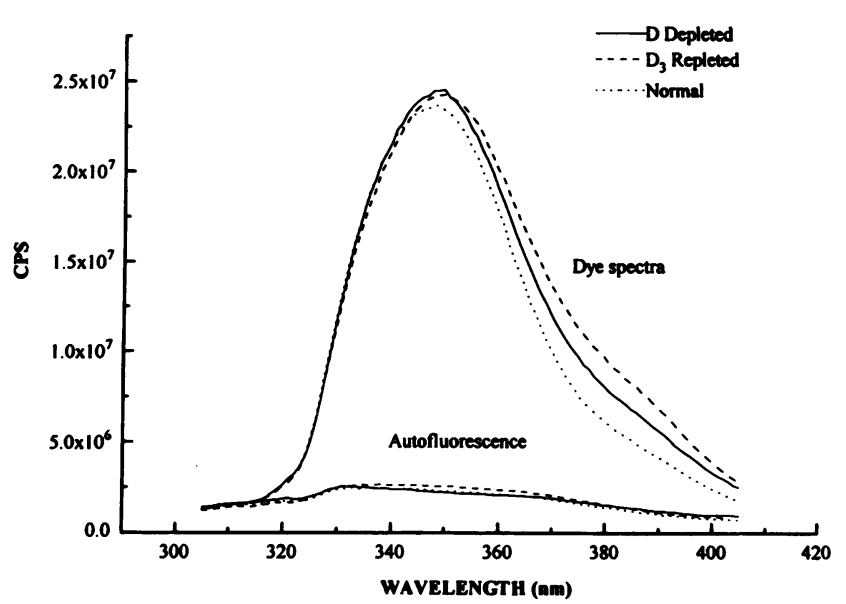

Figure 1. Representative autofluorescence, and dye spectra of Fura-2 AM-loaded hepatocytes obtained from D-deficient, $D_{3}$-repleted, or normal rat livers maintained in vitro in extracellular calcium concentrations similar to those observed in vivo. All dye calibrations were performed in situ. 
by the loss of the fluorescence signal secondary to $\mathrm{Mn}^{2+}$ binding to the Fura-2 probe.

\section{Cellular responses}

Phosphorylase a activity. Phosphorylase $a$ activity, a calcium-dependent enzyme, was measured in order to gain insight into the functional response to phenylephrine in hypo- and normocalcemic conditions. Freshly isolated hepatocytes were diluted in Krebs-Henseleit buffer at a final density of $9 \times 10^{6}$ cells $/ \mathrm{ml}$, and kept in extracellular $\mathrm{Ca}^{2+}$ concentration similar to that observed in vivo. Suspended hepatocytes were incubated for $2 \mathrm{~min}$ either without agonist or in the presence of $8 \mu \mathrm{M}$ phenylephrine. They were subsequently frozen in liquid nitrogen until ready for enzyme determination. Phosphorylase $a$ activity was measured at $30^{\circ} \mathrm{C}$ for $40 \mathrm{~min}$ as already described (11), and the reaction stopped with $10 \%$ TCA. Precipitated proteins were sedimented by centrifugation, and inorganic phosphate measured in the supernatant by the method of Fiske and Subbarow (12). One unit of phosphorylase $a$ represents $1 \mu \mathrm{mol}$ of inorganic phosphate produced per minute $/ 10^{6}$ hepatocytes.

DNA synthesis. The biological response to EGF was investigated by measuring its mitogenic potential in primary culture of hepatocytes obtained from hypocalcemic D-deficient or from normal rat livers. The freshly isolated hepatocytes were resuspended in Williams E medium at an ionized calcium concentration of either 0.8 (D deficient) or 1.25 $\mathrm{mM}$ (normals), and were supplemented with $150 \mu \mathrm{g} /$ liter insulin (Eli Lilly \& Company, Indianapolis, IN), $4 \mu \mathrm{M}$ dexamethasone (Sigma Chemical Co.), $0.25 \mu \mathrm{M}$ pyruvate (Sigma Chemical Co.), $100 \mathrm{U} / \mathrm{ml}$ penicillin $\mathrm{G}$, and $100 \mu \mathrm{g} / \mathrm{ml}$ streptomycin (Gibco BRL, Burlington, Ont., Canada). They were plated in 35-mm diam dishes coated with 3 $\mu \mathrm{g} / \mathrm{cm}^{2}$ fibronectin (Sigma Chemical Co.), at a cell density of $2.5 \times 10^{5}$ per dish. Cells were incubated at $37^{\circ} \mathrm{C}$ under $\mathrm{CO}_{2} /$ air $(5: 95$, vol/vol). After $3 \mathrm{~h}$, the medium was changed to fresh Williams $\mathrm{E}$ medium containing $5 \mathrm{ng} /$ liter insulin, $0.25 \mu \mathrm{M}$ pyruvate, $100 \mathrm{U} /$ liter penicillin, and $100 \mu \mathrm{g} / \mathrm{ml}$ streptomycin. Cells were stimulated with EGF at a concentration of $50 \mathrm{ng} / \mathrm{ml}$.

$\left[{ }^{3} \mathrm{H}\right]$ thymidine incorporation in relation to cell protein was used to evaluate DNA synthesis. $24 \mathrm{~h}$ after plating, $1 \mu \mathrm{Ci} / \mathrm{ml}$ [methyl${ }^{3} \mathrm{H}$ ] thymidine (ICN Canada, spec act, $70-90 \mathrm{Ci} / \mathrm{mmol}$ ) was added to fresh medium. DNA was precipitated $24 \mathrm{~h}$ later for the determination of $\left[{ }^{3} \mathrm{H}\right]$ thymidine incorporation according to Marceau et al. (13). Protein concentration was measured as described by Bradford (14) using crystalline BSA as standard.

Table I. Extracellular Calcium Concentrations

\begin{tabular}{|c|c|c|c|c|}
\hline \multirow[b]{2}{*}{ Parameters } & \multirow{2}{*}{$\begin{array}{l}\text { Hypocalcemic } \\
\text { D deficient }\end{array}$} & \multicolumn{2}{|c|}{ Normocalcemic } & \multirow{2}{*}{$\begin{array}{c}P \\
\text { (ANOVA) }\end{array}$} \\
\hline & & $\mathrm{D}_{3}$ repleted & Normals & \\
\hline \multirow{3}{*}{$\begin{array}{l}\text { In vivo serum } \\
\text { ionized calcium } \\
(m M)\end{array}$} & 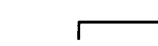 & $P<0.0001-$ & $\longrightarrow$ & \multirow[t]{3}{*}{$<0.0001$} \\
\hline & \multicolumn{3}{|c|}{$\Gamma^{P}<0.00017 \Gamma \mathrm{NS} \longrightarrow$} & \\
\hline & $0.78 \pm 0.02$ & $1.24 \pm 0.03$ & $1.25 \pm 0.01$ & \\
\hline \multirow{3}{*}{$\begin{array}{l}\text { In vitro extracellular } \\
\text { ionized calcium } \\
(m M)\end{array}$} & \multicolumn{3}{|c|}{$\longmapsto P<0.0001 \longrightarrow$} & \multirow[t]{3}{*}{$<0.0001$} \\
\hline & \multicolumn{3}{|c|}{$\ulcorner P<0.00017\ulcorner\mathrm{NS} \longrightarrow$} & \\
\hline & $0.82 \pm 0.01$ & $1.25 \pm 0.01$ & $1.27 \pm 0.01$ & \\
\hline Animals $(n)$ & 12 & 4 & 24 & \\
\hline \multicolumn{5}{|l|}{ Determinations per } \\
\hline
\end{tabular}

In vivo and in vitro ionized calcium concentrations observed in the various groups of animals (in vivo), and in the solutions used during the experimental periods (in vitro). Statistically significant differences between group means were analyzed by a one-way analysis of variance; individual contrasts (bracketed $P$ values) between group means were performed by the Tukey's test.

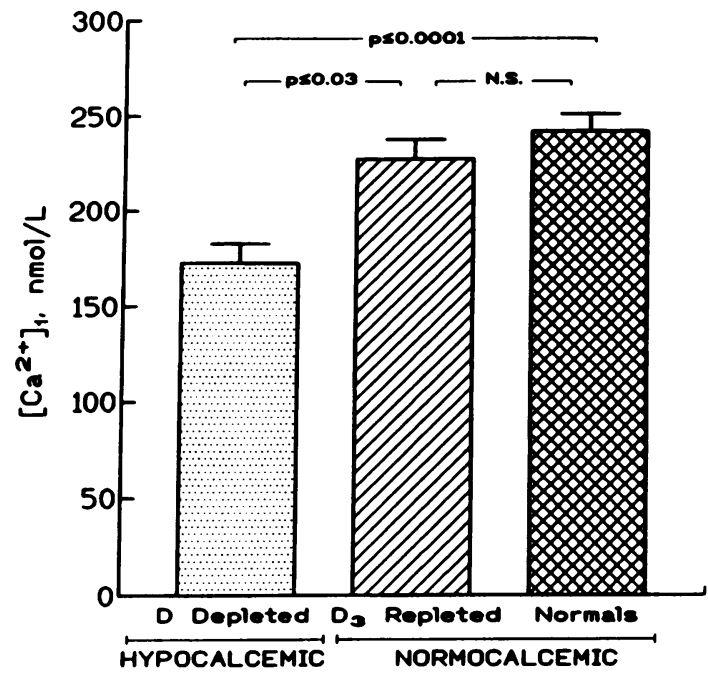

Figure 2. Resting $\left[\mathrm{Ca}^{2+}\right]_{\mathrm{i}}$ in hepatocytes isolated from hypo- or normocalcemic rat livers. Data are presented as means \pm SEM. The number of animals used and number of determinations per animal are presented in Table I. Statistically significant differences between group means were analyzed by a one-way analysis of variance $(P$ $<0.0003$ ) with individual contrasts (bracketed values) between group means performed by the Tukey's test.

\section{Statistical analysis}

Data are presented as means \pm SEM. Statistically significant differences between group means were analyzed by analysis of variance, or by Student's $t$ tests (15) as indicated in the table or figure legends.

\section{Results}

Extracellular calcium conditions. The in vivo serum $\mathrm{Ca}^{2+}$ and in vitro extracellular $\mathrm{Ca}^{2+}$ concentrations used for the determination of $\left[\mathrm{Ca}^{2+}\right]_{i}$ are presented in Table I. Serum $\mathrm{Ca}^{2+}$ was significantly lower in $\mathrm{D}$ deficient rats but $\mathrm{D}_{3}$ supplementation contributed to normalize circulating $\mathrm{Ca}^{2+}$ to concentrations similar to those observed in normal rats. In vitro, hepatocytes were maintained in an extracellular $\mathrm{Ca}^{2+}$ milieu similar to that observed in vivo with concentrations compatible with hypocalcemia in $\mathrm{D}$ deficient or with normocalcemia in $\mathrm{D}_{3}$ repleted and normal rats.

Serum electrolytes, vitamin D metabolites, and hepatic enzymes in similarly treated animals have been reported previously and indicate that liver functions are normal in these animals, whereas serum 25-hydroxyvitamin D (25(OH)D) are at or near undetectable levels and $1,25(\mathrm{OH})_{2} \mathrm{D}$ concentrations significantly decreased $(3,16,17)$. This animal model is regularly used as an experimental paradigm for human vitamin $D$ deficiency and calcium deprivation (18-20).

Resting intracellular calcium concentrations. $\left[\mathrm{Ca}^{2+}\right]_{i}$ in hepatocytes obtained from hypo- or normocalcemic rats are illustrated in Fig. 2. Hepatocytes from hypocalcemic D-deficient rats exhibited significantly lower resting $\left[\mathrm{Ca}^{2+}\right]_{\mathrm{i}}(172 \pm 10 \mathrm{nM})$ than those obtained from $\mathrm{D}_{3}$ repleted $(P<0.03)$ or from normal rats $(P<0.0001)$; no significant difference between hepatocytes of $\mathrm{D}_{3}$-repleted and normal rat livers was observed with $\left[\mathrm{Ca}^{2+}\right]_{\mathrm{i}}$ of $227 \pm 10$ and $242 \pm 9 \mathrm{nM}$, respectively. The coefficient of variation in the measurement of $\left[\mathrm{Ca}^{2+}\right]_{\mathrm{i}}$ did not vary significantly between groups and was $25.1 \%, 24.2 \%$, and $20.3 \%$ in the 
D-deficient, $\mathrm{D}_{3}$-repleted, and normal rats respectively, a range compatible with that of others (21). Owing to the equivalence in basal $\left[\mathrm{Ca}^{2+}\right]_{i}$ between hepatocytes isolated from $\mathrm{D}_{3}$-repleted and normal rat livers, all subsequent studies were performed using hepatocytes obtained from normal rats as representative of the normocalcemic group.

When paired hepatocytes were equilibrated in vitro in $\left[\mathrm{Ca}^{2+}\right]_{\mathrm{e}}$ compatible with states of hypo- or normocalcemia, it was found that the in vitro extracellular $\mathrm{Ca}^{2+}$ milieu did not significantly influence $\left[\mathrm{Ca}^{2+}\right]_{\mathrm{i}}$. In hepatocytes from normal rat livers, resting $\left[\mathrm{Ca}^{2+}\right]_{\mathrm{i}}$ was $230 \pm 13$ and $241 \pm 17 \mathrm{nM}(n=7)(\mathrm{NS})$ in the presence of extracellular $\mathrm{Ca}^{2+}$ of $0.84 \pm 0.01$ and $1.27 \pm 0.01 \mathrm{mM}$, respectively. Similarly, when hepatocytes of hypocalcemic rats were equilibrated in vitro in extracellular $\mathrm{Ca}^{2+}$ concentrations of $0.82 \pm 0.02$ or $1.24 \pm 0.05 \mathrm{mM},\left[\mathrm{Ca}^{2+}\right]_{\mathrm{i}}$ remained stable at $110 \pm 2$ and $105 \pm 19 \mathrm{nM}(n=2)(\mathrm{NS})$.

Agonist-stimulated intracellular calcium responses. To evaluate the effect of the prevailing in vivo ionized calcium concentrations on cell responses, $\left[\mathrm{Ca}^{2+}\right]_{i}$ was evaluated in cell preparations kept in vitro at extracellular $\mathrm{Ca}^{2+}$ concentrations similar to those observed in each animal.

Fig. 3 presents the mean maximum $\left[\mathrm{Ca}^{2+}\right]_{\mathrm{i}}$ achieved after stimulation with phenylephrine while typical $\left[\mathrm{Ca}^{2+}\right]_{i}$ responses for the two groups studied are illustrated in Fig. 4. Application of $8 \mu \mathrm{M}$ phenylephrine stimulated the mobilization of $\left[\mathrm{Ca}^{2+}\right]_{i}$ in both groups. Peak $\left[\mathrm{Ca}^{2+}\right]_{\mathrm{i}}$ was similar in both groups reaching $401.6 \pm 43.3(+115 \pm 19 \%$ over paired basal values, $P$ $<0.0001$ ) in hepatocytes obtained from hypocalcemic D-defi-

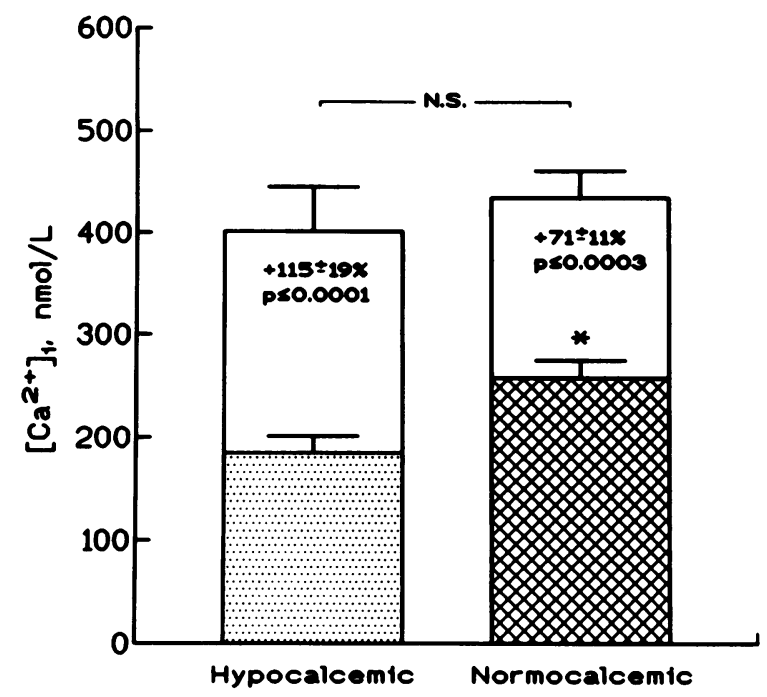

Figure 3. Peak $\left[\mathrm{Ca}^{2+}\right]_{\mathrm{i}}$ attained after stimulation of rat hepatocyte couplets with $8 \mu \mathrm{M}$ phenylephrine. Freshly isolated hepatocytes were kept in short-term primary culture $(1 \mathrm{~h})$ and maintained in vitro in extracellular $\mathrm{Ca}^{2+}$ concentrations similar to those observed in vivo. Data are illustrated as basal ( $\square$,國), and phenylephrine-stimulated ( $\square$ ) values. Hepatocytes were obtained from hypocalcemic D-deficient $(\square, \square ; n=14)$, or normal (慻, $\square ; n=8)$ rat livers. The number indicated in each column represents the mean percent increase over paired basal values for each group of animals studied. Statistically significant differences between group means were evaluated by the unpaired Student's $t$ test while the increase over respective basal values was evaluated by the paired Student's $t$ test. The bracketed value represents the significance in peak $\left[\mathrm{Ca}^{2+}\right]_{\mathrm{i}}$ achieved under phenylephrine stimulation; *Difference between the two groups in basal $\left[\mathrm{Ca}^{2+}\right]_{i}$, $P<0.02$.

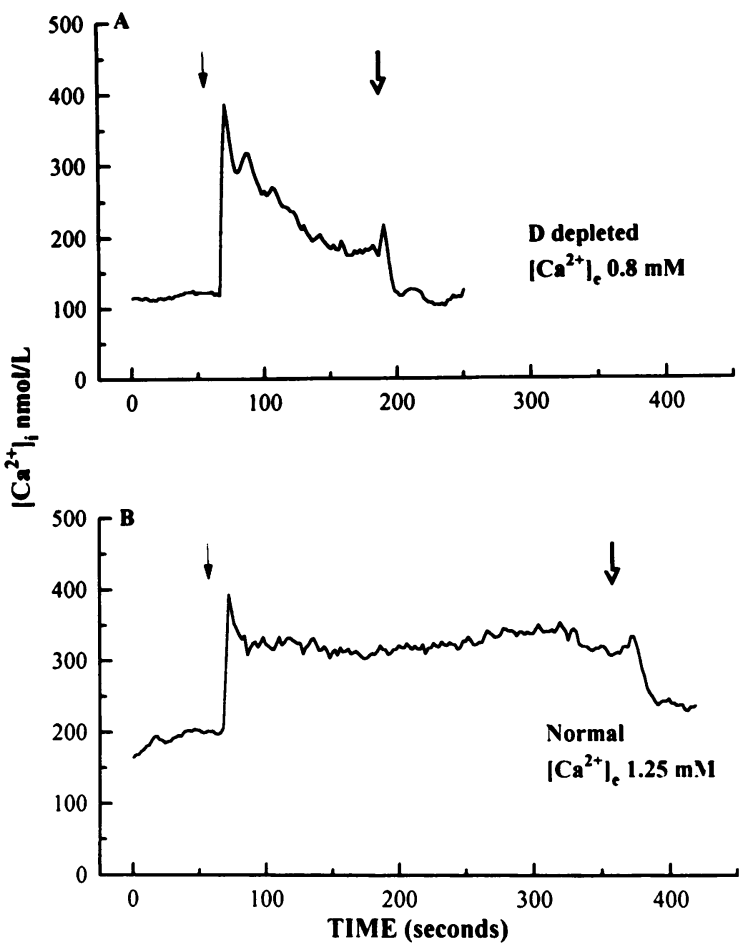

Figure 4. Illustration of a typical $\left[\mathrm{Ca}^{2+}\right]_{\mathrm{i}}$ responses after stimulation with phenylephrine. Hepatocyte couplets were obtained from livers of $(A)$ hypocalcemic D-deficient, maintained in extracellular $\mathrm{Ca}^{2+}$ of $0.8 \mathrm{mM}$ or $(B)$ normal rats maintained in extracellular $\mathrm{Ca}^{2+}$ of 1.25 mM. $(\cdot \rightarrow)$ and $(\rightarrow)$ indicate the beginning and the end of phenylephrine perfusion, respectively.

cient rats, and $433.6 \pm 27.6 \mathrm{nM}(+71 \pm 11 \%, P<0.0003)$ in those obtained from normal rats (NS). In several cases $(\sim 50 \%)$, chronic hypocalcemia modified the patternof response to phenylephrine whereby $\left[\mathrm{Ca}^{2+}\right]_{\mathrm{i}}$ rapidly decayed after an initial peak as opposed to a consistantly sustained elevation observed in cells from normocalcemic animals (Fig. 4).

Figs. 5 and 6 present the $\left[\mathrm{Ca}^{2+}\right]_{\mathrm{i}}$ response after EGF stimulation in hypocalcemic D-deficient and in normal rat hepatocytes. Although EGF stimulated increases in $\left[\mathrm{Ca}^{2+}\right]_{\mathbf{i}}$ in both groups, calcium deficiency highly influenced the response to EGF with mean $\left[\mathrm{Ca}^{2+}\right]_{i}$ peaks reaching only $237.6 \pm 18.7$ ( $+67 \pm 12 \%$ over paired basal values, $P<0.0001$ ) as compared to $605.2 \pm 89.9 \mathrm{nM}(+120 \pm 26 \%, P<0.006)$ in hepatocytes obtained from normal rat livers $(P<0.0001)$ where a sustained response was also observed during the course of EGF stimulation as illustrated in Fig. 6.

The data obtained on the evaluation of $\mathrm{Ca}^{2+}$ entry using $\mathrm{Mn}^{2+}$ as indicator are presented in Fig. 7 and in Table II. As illustrated in the representative traces (Fig. 7), extracellular $\mathrm{Ca}^{2+}$ influenced the entry of $\mathrm{Mn}^{2+}$ into hepatocytes after stimulation by both phenylephrine and EGF as indicated by the $\mathrm{Mn}^{2+}$-mediated fluorescence quenching of the Fura-2 signal. Calculation of the slopes of the decay in the Fura-2 fluorescence signal after phenylephrine or EGF exposure (Table II) shows that for both agonists $\mathrm{Mn}^{2+}$ entry was significantly decreased in low $\left[\mathrm{Ca}^{2+}\right]_{\mathrm{e}}$ compared to that observed in normal $\left[\mathrm{Ca}^{2+}\right]_{\mathrm{e}}$ condition $(P<0.03)$.

Biological responses. The ATP-dependent $\mathrm{Ca}^{2+}$ transport observed in liver plasma membrane vesicles of hypo- and nor- 


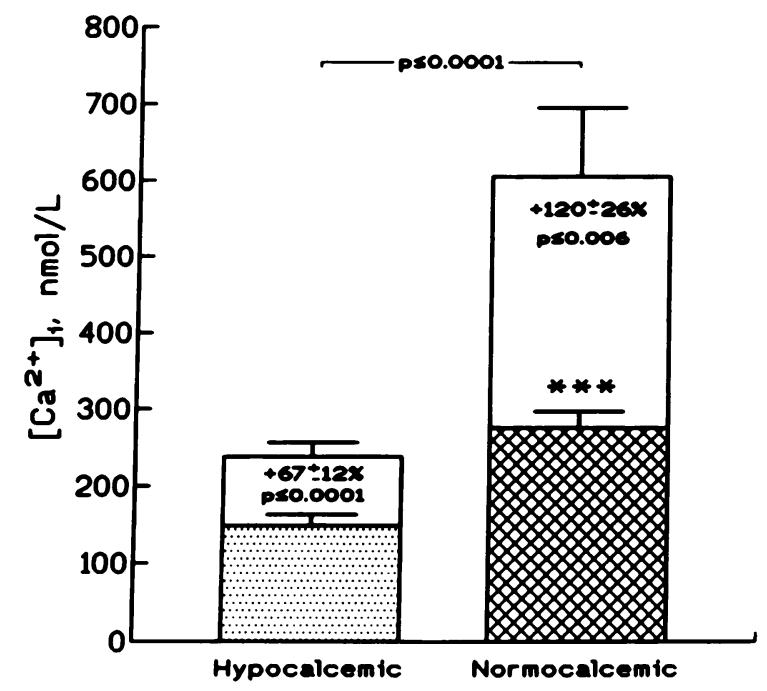

Figure 5. Peak $\left[\mathrm{Ca}^{2+}\right]_{\mathrm{i}}$ attained after stimulation of rat hepatocyte couplets with $8.2 \mathrm{nM}$ EGF. Freshly isolated hepatocytes were kept in short-term primary culture $(1 \mathrm{~h})$ and maintained in vitro in extracellular $\mathrm{Ca}^{2+}$ concentrations similar to those observed in vivo. Data are illustrated as basal ( $\square$,圖), and EGF-stimulated $(\square)$ values. Hepatocytes were obtained from hypocalcemic D-deficient $(\square, \square ; n=7)$, or normal (畻, $\square ; n=7$ ) rat livers. The number indicated in each column represents the mean percent increase over paired basal values for each animal studied. Statistically significant differences between group means were evaluated by the Student's $t$ test while the increase over respective basal values was evaluated by the paired Student's $t$ test. The bracketed value represents the significance in peak $\left[\mathrm{Ca}^{2+}\right]_{\mathrm{i}}$ achieved under EGF stimulation; ${ }^{* * *}$ Difference between the two groups in basal $\left[\mathrm{Ca}^{2+}\right]_{\mathrm{i}}, P<0.0003$.

mocalcemic rats is presented in Fig. 8. As illustrated, no significant difference in the cytoplasmic $\mathrm{Ca}^{2+}$ ATPase was observed between the two groups with $K_{\mathrm{m}}$ values of $7.20 \pm 6.53$ and $15.33 \pm 4.51 \mathrm{nM}$ while $B_{\max }$ was estimated at $1.55 \pm 0.39$ and $1.88 \pm 0.18 \mathrm{nmol}{ }^{45} \mathrm{Ca}$ per $30 \mathrm{~s} / \mathrm{mg}$ protein after normal and hypocalcemic conditioning, respectively.

The basal and phenylephrine-stimulated phosphorylase $a$ activities are presented in Table III. As indicated, resting phosphorylase $a$ activity was similar in hepatocytes obtained from normo- and hypocalcemic rat livers. Phenylephrine increased enzyme activity in both groups by $0.45 \pm 0.09(P<0.042)$ and $0.55 \pm 0.05(P<0.009) \mu \mathrm{mol} \mathrm{P}_{\mathrm{i}} / \mathrm{min}$ per $10^{6}$ hepatocytes in the hypo- and normocalcemic group, respectively, thus indicating similar stimulation of phosphorylase $a$ activity above baseline in response to phenylephrine.

The biological response to EGF was measured by its capacity to stimulate DNA synthesis and is presented in Table IV. Hypocalcemia significantly impaired EGF-induced DNA synthesis as evidenced by a $50 \%$ decrease in $\left[{ }^{3} \mathrm{H}\right]$ thymidine incorporation compared to the response observed in hepatocytes obtained from normocalcemic animals $(P<0.03)$.

\section{Discussion}

The data obtained during the present studies show, for the first time, that long-lasting hypocalcemia secondary to D deficiency can lead to a significant lowering of resting $\left[\mathrm{Ca}^{2+}\right]_{i}$ in rat hepatocytes maintained in vitro in extracellular $\mathrm{Ca}^{2+}$ concentrations similar to those observed in vivo. Correction of hypocal- cemia by repletion with $D_{3}$ (leading to normal circulating $D_{3}$ metabolites as already reported [3]) contributes in normalizing both the circulating calcium and the $\left[\mathrm{Ca}^{2+}\right]_{\mathrm{i}}$ to a level similar to that observed in normal rats. These data clearly illustrate that despite the large concentration gradient between extra- (millimolar range) and intracellular (nanomolar range) $\mathrm{Ca}^{2+}$, a physiologically relevant lowering of extracellular $\mathrm{Ca}^{2+}$ concentration in vivo has indeed a significant impact on resting $\left[\mathrm{Ca}^{2+}\right]_{i}$. Although surprising, others have, in fact, reported a $K_{\mathrm{m}}$ for extracellular $\mathrm{Ca}^{2+}$ as high as $10 \mathrm{mM}$ for the plasma membrane $\mathrm{Ca}^{2+}$ pump (trans activity) (22), which suggests that, in the hypo- to normocalcemic range, substantial changes in the kinetics of $\mathrm{Ca}^{2+}$ movement can be expected. Interestingly, in vitro variations in extracellular $\mathrm{Ca}^{2+}$ do not seem to influence resting $\left[\mathrm{Ca}^{2+}\right]_{\mathrm{i}}$ as short-term $(1-2 \mathrm{~h})$ equilibration of paired hepatocytes in extracellular $\mathrm{Ca}^{2+}$ concentrations in vitro compatible with states of hypo- or normocalcemia in vivo did not significantly influence $\left[\mathrm{Ca}^{2+}\right]_{i}$ in hepatocytes obtained from normal or D-deficient rats. This observation indicates that the in vivo calcium status is the main determinant of the resting $\left[\mathrm{Ca}^{2+}\right]_{i}$, and may explained why acute in vitro changes in $\left[\mathrm{Ca}^{2+}\right]_{e}$ have, up to now, been reported not to influence $\left[\mathrm{Ca}^{2+}\right]_{\mathrm{i}}$. It is not excluded, however, that longer equilibration periods in vitro and/or the presence of active metabolic demands on the cells may be required to fully simulate the in vivo influence of extracellular $\mathrm{Ca}^{2+}$ on the hepatocyte.

In an attempt to investigate the mechanisms involved in the resting as well as in the subobtimal $\left[\mathrm{Ca}^{2+}\right]_{i}$ responses induced by hypocalcemia, the activity of the plasma membrane ATP-

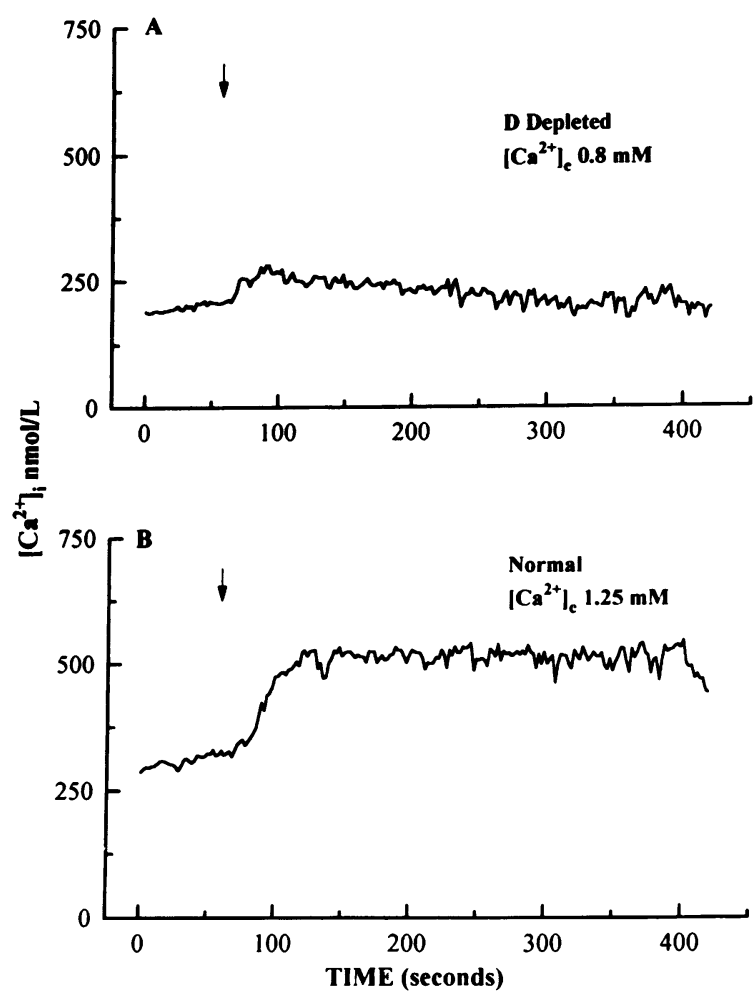

Figure 6. Illustration of a typical $\left[\mathrm{Ca}^{2+}\right]_{\mathrm{i}}$ responses after stimulation with EGF. Hepatocyte couplets were obtained from livers of $(A)$ hypocalcemic D-deficient, maintained in extracellular $\mathrm{Ca}^{2+}$ of $0.8 \mathrm{mM}$ or $(B)$ normal rats, maintained in extracellular $\mathrm{Ca}^{2+}$ of $1.25 \mathrm{mM}$. $(\rightarrow)$ indicates the beginning of EGF perfusion. 
Phenylephrine Stimulation
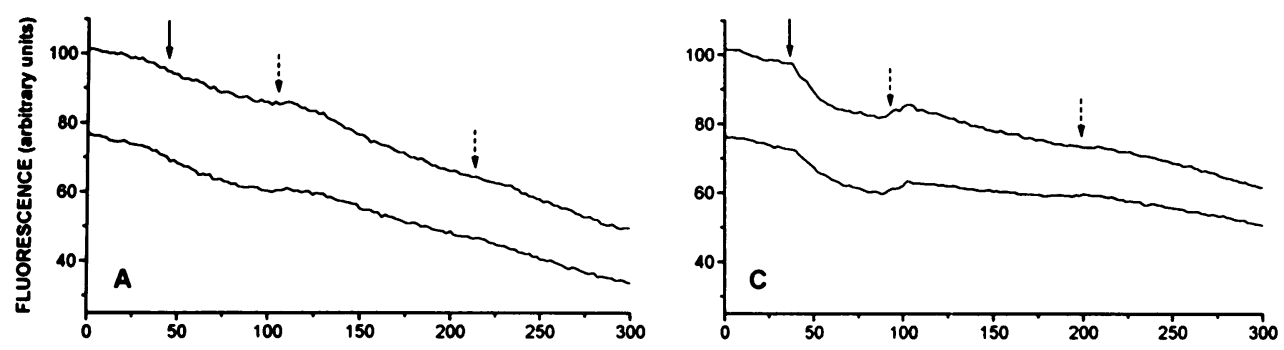

\section{EGF Stimulation}
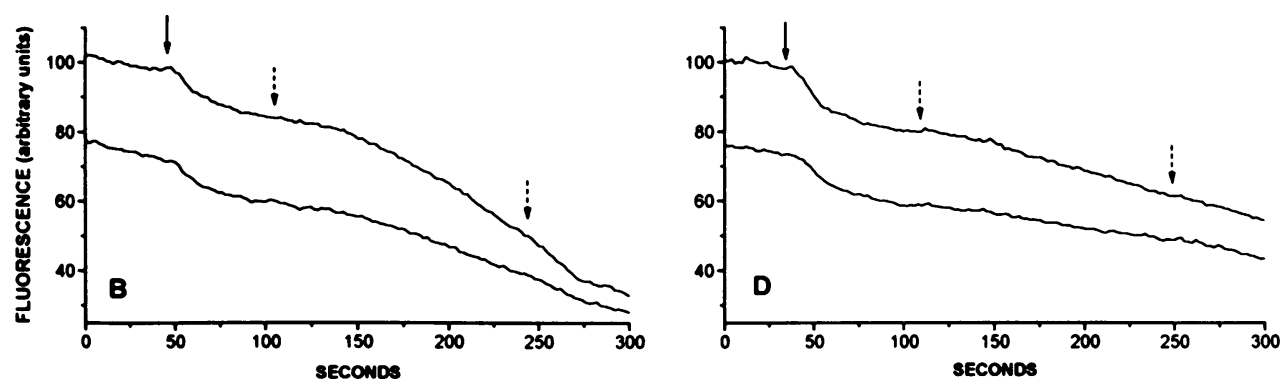

Figure 7. Representative traces of the extracellular $\mathrm{Mn}^{2+}$-mediated fluorescence quenching of the Fura-2 signal evaluated at 334 (top trace) and $360 \mathrm{~nm}$ (bottom trace). Hepatocytes were isolated from hypo- or normocalcemic rat livers and maintained for $1 \mathrm{~h}$ in primary culture in an $\left[\mathrm{Ca}^{2+}\right]_{e}$ environment similar to that observed in vivo.

Extracellular Mn was added at a concentration of $500 \mu \mathrm{M}$ as indicated by the solid arrows $(\rightarrow)$. Agonist application was added as indicated by the dashed arrows $(-\rightarrow)$.

dependent $\mathrm{Ca}^{2+}$ transport has been investigated. Our data indicate that the cis-affinity of the $\mathrm{Ca}^{2+}$ ATPase is in the order of 1-2 nM in hepatic membranes obtained from both normal and hypocalcemic rats, a value entirely comparable to that reported previously (23). The $\mathrm{Ca}^{2+}$ ATPase capacity of these membranes was also found to be unchanged by chronic hypocalcemia. These observations indicate that the cytoplasmic $\mathrm{Ca}^{2+}$ pump remains unchanged by hypocalcemia and cannot, therefore, be identified as responsible for the lower than normal resting $\left[\mathrm{Ca}^{2+}\right]_{i}$ in D-deficient, hypocalcemic animals. The state of the intracellular calcium pools and their involvment in the resting cytoplasmic $\mathrm{Ca}^{2+}$ concentration is not presently known and further studies will certainly have to address these questions

Table II. Slopes of the Extracellular $\mathrm{Mn}^{2+}$-mediated Fluorescence Quenching of the Fura-2 Signal upon Agonist Stimulation

\begin{tabular}{lccc}
\hline & \multicolumn{3}{c}{ Group } \\
\cline { 2 - 3 } & $\begin{array}{c}\text { Normocalcemic } \\
\text { (slopes) }\end{array}$ & $\begin{array}{c}\text { Hypocalcemic } \\
\text { (slopes) }\end{array}$ & $P$ \\
\hline $\begin{array}{c}\text { Phenylephrine } \\
(8 \mu \mathrm{M})\end{array}$ & $-0.2151 \pm 0.0057$ & $-0.1528 \pm 0.0016$ & $<0.03$ \\
$\begin{array}{l}\text { EGF } \\
(8.2 \mathrm{nM})\end{array}$ & $-0.3729 \pm 0.0226$ & $-0.1674 \pm 0.0271$ & $<0.03$ \\
\hline
\end{tabular}

Hepatocytes were isolated from hypo- or normocalcemic rat livers and maintained for one hour in primary culture containing $\left[\mathrm{Ca}^{2+}\right]_{e}$ similar to that observed in vivo. The Fura-2 fluorescence quenching by $\mathrm{Mn}^{2+}$ was obtained as mentioned in Fig. 7. Data represent mean $\pm \mathrm{SEM}$, and were obtained in hepatocytes isolated from three animals. Statistically significant differences between group means were evaluated by the Student's $t$ test for each agonist studied. most particularly in the light that emptying of the intracellular calcium stores initiates an accelerated entry of extracellular $\mathrm{Ca}^{2+}$ into the cellular compartment (24).

The respective role of $\mathrm{D}$ deficiency and of its induced functional calcium deprivation in the observed lowering of resting and agonist-stimulated $\left[\mathrm{Ca}^{2+}\right]_{i}$ have not been addressed during the present studies. Indeed, the aim of our studies was to carefully evaluate in vitro the cellular consequences of the prevailing in vivo ionized calcium on the hepatocyte $\left[\mathrm{Ca}^{2+}\right]_{\mathrm{i}}$ taking great care not to disturb the extracellular steady-state $\mathrm{Ca}^{2+}$ environment. It is postulated that most likely both the $\mathrm{D}$ and the calcium status contribute in maintaining the $\left[\mathrm{Ca}^{2+}\right]_{i}$ homeostasis in vivo. Indeed, the $\mathrm{D}$ endocrine system, acting through specific genomic actions, or through effects on calcium homeostasis, may be partly responsible for the observed effect on $\left[\mathrm{Ca}^{2+}\right]_{\mathrm{i}}$ as $1,25(\mathrm{OH})_{2} \mathrm{D}_{3}$ has been reported to influence basal $\left[\mathrm{Ca}^{2+}\right]_{\mathrm{i}}$ in vitro in the HL-60 cell line (25) and to stimulate calcium mobilization in several cell types (26-30). At the membrane level, the $\mathrm{D}$ endocrine system is also known to influence membrane fluidity (31), phospholipid composition (32), phosphoinositide turnover (26), several protein kinases $(26,33$, 34), as well as the transcription of the inositol trisphosphate receptor gene (35), all of which may influence cellular calcium metabolism and the transduction of signals linked to $\mathrm{Ca}^{2+}$ mobilization. On the other hand, in other cell types, extracellular $\mathrm{Ca}^{2+}$ alone can influence $\left[\mathrm{Ca}^{2+}\right]_{\mathrm{i}}$ as exemplified in keratinocytes where $\left[\mathrm{Ca}^{2+}\right]_{i}$ has been shown to be sensitive in vitro to small changes in extracellular calcium concentrations (36), and to be influenced by the state of differentiation of the cells (37). Moreover, extracellular calcium, independantly of the D status, has also been reported to influence liver EGF receptor density and autophosphorylation indicating that the observed perturbed $\left[\mathrm{Ca}^{2+}\right]_{\mathrm{i}}$ response to EGF stimulation may be partly 


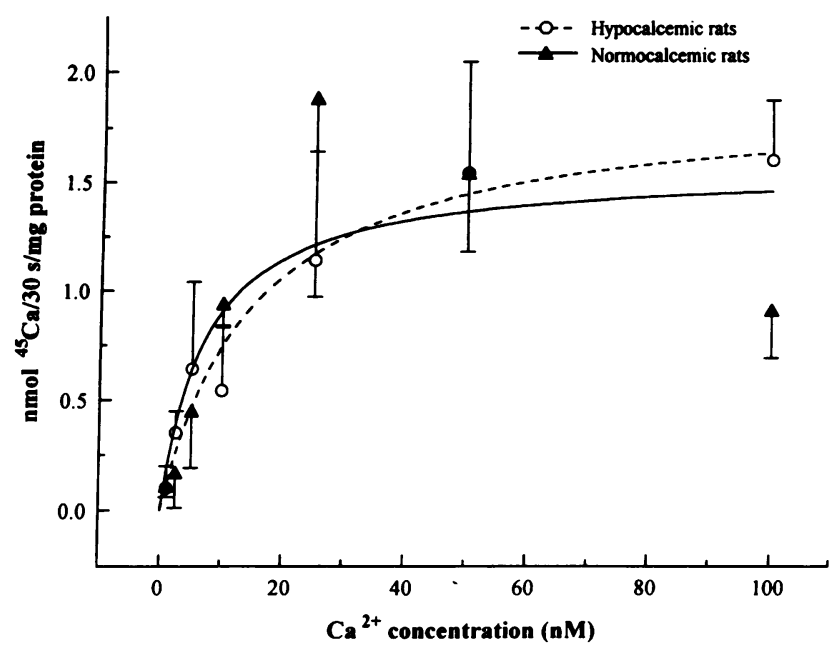

Figure 8. Hepatic ATP-dependent $\mathrm{Ca}^{2+}$ transport. Plasma membrane vesicules were prepared from hypo- or normocalcemic rat livers and ATP-dependent $\mathrm{Ca}^{2+}$ transport activity measured. Data are the mean \pm SEM of triplicate determinations. Values for $K_{\mathrm{m}}$ were $7.20 \pm 6.5$ and $15.33 \pm 4.51$, nM, while $B_{\max }$ was estimated at $1.55 \pm 0.39$ and $1.88 \pm 0.18 \mathrm{nmol}{ }^{45} \mathrm{Ca}$ per $30 \mathrm{~s} / \mathrm{mg}$ protein after normal and hypocalcemic conditioning, respectively.

due to a failure in the EGF receptor transduction apparatus brought about by hypocalcemia (38). In intact animals, however, it is difficult to dissociate the effect of calcium from that of the calcium regulating hormones as they are intimately interrelated with changes in any of the parameters of calcium homeostasis triggering compensatory changes in the others. Ongoing experiments indicate, however, that the in vitro correction of the $\left[\mathrm{Ca}^{2+}\right]_{e}$ environment of hepatocytes obtained from hypocalcemic rat livers influences neither the $\left[\mathrm{Ca}^{2+}\right]_{i}$ nor the cellular response to EGF as evaluated by it capacity to induce DNA synthesis over a period of 24-48 $\mathrm{h}$ (unpublished data).

The short- and long-term consequences of lower than normal $\left[\mathrm{Ca}^{2+}\right]_{i}$ on cell function are not known. The question

Table III. Influence of the In Vivo Calcium Status on the Activity of the Hepatic Phosphorylase a

\begin{tabular}{|c|c|c|c|}
\hline & \multicolumn{2}{|c|}{ Group } & \multirow[b]{2}{*}{$P$} \\
\hline & Normocalcemic & Hypocalcemic & \\
\hline & \multicolumn{2}{|c|}{ umol $P_{i} /$ min per $10^{6} \mathrm{cells}$} & \\
\hline Basal & $0.42 \pm 0.19$ & $0.66 \pm 0.25$ & NS \\
\hline $\begin{array}{l}\text { Phenylephrine-stimulated } \\
\qquad(8 \mu \mathrm{M})\end{array}$ & $0.97 \pm 0.15$ & $1.11 \pm 0.15$ & NS \\
\hline
\end{tabular}

Hepatocytes were obtained from hypocalcemic or normocalcemic rat livers and maintained in vitro at all times at $\left[\mathrm{Ca}^{2+}\right]_{e}$ similar to those observed in vivo. All determinations were done in duplicate in hepatocytes obtained from three hypo- and three normocalcemic rats. Statistically significant differences between group means (hypocalcemic vs normocalcemic) were evaluated by the Student's $t$ test. Differences between basal and stimulated mean values were evaluated by the paired Student's $t$ test: Hypocalcemic $P<0.05$; Normocalcemic $P<0.009$ ).
Table IV. Influence of the In Vivo Extracellular Calcium Concentration on the EGF-mediated DNA Synthesis Response

\begin{tabular}{llll}
\hline & \multicolumn{2}{c}{ Experimental condition } & \\
\cline { 2 - 3 } & Normocalcemic & Hypocalcemic & $P$ \\
\hline $\begin{array}{l}\text { In vivo }\left[\mathrm{Ca}^{2+}\right]_{e} \\
(\mathrm{mM})\end{array}$ & $1.26 \pm 0.02$ & $0.78 \pm 0.05$ & $<0.0001$ \\
$\begin{array}{l}\text { In vitro }\left[\mathrm{Ca}^{2+}\right]_{e} \\
(m M)\end{array}$ & $1.24 \pm 0.01$ & $0.78 \pm 0.02$ & $<0.001$ \\
$\begin{array}{l}\left.{ }^{3} \mathrm{H}\right] \text { thymidine incorporation } \\
\text { (percentage of base value) }\end{array}$ & $411 \pm 52$ & $206 \pm 53$ & $<0.03$ \\
\hline
\end{tabular}

Hepatocytes were obtained from hypocalcemic or normocalcemic rat livers and maintained in vitro at all times at $\left[\mathrm{Ca}^{2+}\right]_{e}$ similar to those observed in vivo. DNA synthesis was evaluated in primary hepatocyte culture. All determinations were done in duplicate in hepatocytes obtained from three hypocalcemic and six normocalcemic rats. Statistically significant differences between group means was evaluated by the Student's $t$ test.

arises, however, as to the impact of calcium deficiency on the integrity of the many calcium dependent metabolic pathways, the cell secretory apparatus as well as the full integrity of the receptor-operated cell responses which are mediated through the calcium signaling cascade. The data obtained during the present studies may contribute to explain some of these observations by clearly showing that chronic hypocalcemia of $D$ deficiency leads to abnormal responses in the intensity as well as in the pattern of the $\left[\mathrm{Ca}^{2+}\right]_{\mathrm{i}}$ movements after stimulation with both EGF, and the $\alpha_{1}$-adrenergicreceptor agonist phenylephrine. Recent studies have, indeed, shown that hypocalcemia of $D$ deficiency perturbs compensatory hepatic growth in vivo after two-thirds partial hepatectomy (3) while the present studies indicate that the EGF-mediated rise in $\left[\mathrm{Ca}^{2+}\right]_{i}$ as well as in DNA synthesis are greatly dampened in vitro by the in vivo hypocalcemic status. These observations reinforce the contention that several key pathways linked to intracellular calcium homeostasis may be perturbed by chronic hypocalcemia. Indeed, EGF is known to act through autophosphorylation of its membrane receptor (39) subsequently leading to changes in intracellular calcium fluxes partly through activation of phospholypase $\mathrm{C}_{\gamma}(40,41)$ but also via the participation of extracellular calcium (42). Phenylephrine, on the other hand, is a classical calcium mobilizing agent acting through receptor mediated phosphatidyl inositol phosphate turnover and intracellular calcium mobilization via the $\mathrm{IP}_{3}$ responsive domains of the endoplasmic reticulum (43). Our data using $\mathrm{Mn}^{2+}$ as a $\mathrm{Ca}^{2+}$ surrogate suggest that $\left[\mathrm{Ca}^{2+}\right]_{e}$ in the hypocalcemic range is associated with a decrease in extracellular $\mathrm{Ca}^{2+}$ contribution to the $\left[\mathrm{Ca}^{2+}\right]_{\mathrm{i}}$ response following both phenylephrine and EGF application. Collectively, these observations indicate that chronic hypocalcemia is associated not only with a lowering of resting $\left[\mathrm{Ca}^{2+}\right]_{\mathrm{i}}$ but also with changes in cellular responses linked to signals needing the calcium transduction system for full activation as exemplified by the response to $\operatorname{EGF}(40,44)$ and phenylephrine $(45,46)$.

Contrary to the hepatocyte EGF-dependent DNA synthesis, phosphorylase $a$ activity was found to remain unchanged by hypocalcemia. This observation was not unexpected as the 
activity of phophorylase $a$ is known to be very sensitive to $\left[\mathrm{Ca}^{2+}\right]_{\mathrm{i}}$ surges. It is therefore postulated that the enzyme most likely responded to the phenylephrine-induced initial rise in cytosolic $\mathrm{Ca}^{2+}$ which was found to remain unchanged in hypocalcemia. Cell activity demanding more sustained calcium responses such as those involved in endogenous secretion may, on the other hand, be perturbed by hypocalcemia. Bile secretion, for example, has indeed been found to be stimulated in rats subjected to $1,25(\mathrm{OH})_{2} \mathrm{D}_{3}$ administration leading to normocalcemia when compared to animals kept in a state of $D$ deficiency and hypocalcemia (47).

The observation that the resting $\left[\mathrm{Ca}^{2+}\right]_{\mathrm{i}}$ is sensitive to long standing hypocalcemia in hepatocytes, a cell type not considered as a classical target for the calcium regulating hormones, also raises the possibility that other cell types may be sensitive to the endocrine calcium/vitamin D status in vivo most particularly those cells responsive to $\mathrm{PTH}, 1,25(\mathrm{OH})_{2} \mathrm{D}_{3}$, and calcitonin. In conclusion, our data show that in unstimulated rat hepatocytes, the in vivo endocrine calcium status has a significant bearing on $\left[\mathrm{Ca}^{2+}\right]_{i}$. This raises the possibility that a lower than normal $\left[\mathrm{Ca}^{2+}\right]_{i}$ may be linked, in calcium disorders, to inappropriate cell responses mediated through the calcium signaling pathway as illustrated, in the present studies, by the response to phenylephrine and EGF.

\section{Acknowledgments}

The authors express their gratitude to Dr. Raynald Laprade for his expert advice in the measurement of $\left[\mathrm{Ca}^{2+}\right]_{i}$, to Mr. Jean-Luc Petit and Ms. Diane Vallerand for their expert technical assistance, and to Ms. Manon Cordeau for her excellent secretarial assistance.

Dr. Pierre Haddad is a Chercheur boursier from the Fonds de la Recherche en Santé du Québec, and Mr. Sébastien Provencher is the recipient of a Studentship Award from the Canadian Liver Foundation. The studies were supported by the Medical Research Council of Canada.

\section{References}

1. Putney, J. W., Jr 1990. Receptor-regulated calcium entry. Pharmacol. Ther. 48:427-434.

2. Kass, G. E. N., J. Llopis, S. C. Chow, S. K. Duddy, and S. Orrenius. 1990. Receptor-operated calcium influx in rat hepatocytes: identification and characterization using manganese. J. Biol. Chem. 265:17486-17492.

3. Ethier, C., R. Kestekian, C. Beaulieu, C. Dubé, J. Havrankova, and M. Gascon-Barré. 1990. Vitamin D depletion retards the normal regeneration process following partial hepatectomy in the rat. Endocrinology. 126:2947-2959.

4. Guroff, G., H. F. DeLuca, and H. Steenbock. 1963. Citrate and action of vitamin D on calcium and phosphorus metabolism. Am. J. Physiol. 204:833836.

5. Berry, M. N., and D. S. Friend. 1969. High-yield preparation of isolated rat liver parenchymal cells. J. Cell Biol. 43:502-506.

6. Graf, J., A. Gautam, and J. L. Boyer. 1984. Isolated rat hepatocyte couplets: a primary secretory unit for electrophysiologic studies of bile secretory function. Proc. Natl. Acad. Sci. USA. 81:6516-6520.

7. Grynkiewicz, G., M. Poeni, and R. Y. Tsien. 1986. A new generation of $\mathrm{Ca}^{2+}$ indicators with greatly improved fluorescence properties. J. Biol. Chem. 260:3440-3450.

8. Tsien, R. Y., T. J. Rink, and M. Poenie. 1985. Measurement of cytosolic free $\mathrm{Ca}^{2+}$ in individual small cells using fluorescence microscopy and dual excitation wavelenghts. Cell Calcium. 6:145-157.

9. Prpic, V., K. C. Green, P. F. Blackmore, and J. H. Exton. 1984. Vasopressin-, angiotensin II-, and alpha 1 -adrenergic-induced inhibition of $\mathrm{Ca}^{2+}$ transport by rat liver plasma membrane vesicles. J. Biol. Chem. 259:1382-1385.

10. Jouneaux, C., Y. Audigier, P. Goldsmith, F. Pecker, and S. Lotersztajn. 1993. Gs mediates hormonal inhibition of the calcium pump in liver plasma membranes. J. Biol. Chem. 268:2368-2372.
11. Hue, L., F. Bontemps, and H. G. Hers. 1975. The effect of glucose and of potassium ions on the interconversion of the two forms of glycogen phosphorylase and of glycogen synthase in isolated rat liver preperations. Biochem. J. 152:105-114.

12. Fiske, C. H., and Y. Subbarow. 1925. Colorimetric determination of phosphorus. J. Biol. Chem. 66:375-400.

13. Marceau, N., M. Noël, and J. Deschesnes. 1982. Growth and functional activities of neonatal and adult rat hepatocytes cultured on fibronectin coated substratum in serum-free medium. In Vitro (Rockville). 18:1-11.

14. Bradford, M. M. 1976. A rapid and sensitive method for the quantitation of microgram quantities of protein utilizing the principle of protein-dye binding. Anal. Biochem. 72:248-254.

15. Winer, B. J. 1971. Statistical Principles in Experimental Design. McGrawHill, Inc., New York. 309 pp.

16. Dubé, C., S. Vallières, C. Éthier, N. Benbrahim, C. Tremblay, and M. Gascon-Barré. 1991. In micronodular cirrhosis, hepatocytes retain a normal C-25 hydroxylation capacity toward vitamin $\mathrm{D}_{3}$ : a study using the rat $\mathrm{CCl}_{4}$-induced cirrhotic model. Hepatology. 13:489-499.

17. Lemay, J. and M. Gascon-Barré. 1992. Responsiveness of the intestinal 1,25-dihydroxivitamin $\mathrm{D}_{3}$ receptor to magnesium depletion in the rat. Endocrinology. 130:2767-2777.

18. Naveh-Many, T., R. Marx, E. Keshet, J. W. Pike, and J. Silver. 1990. Regulation of 1,25-dihydroxyvitamin $D_{3}$ receptor gene expression by 1,25-dihydroxyvitamin $\mathrm{D}_{3}$ in the parathyroid in vivo. J. Clin. Invest. 86:1968-1975.

19. Naveh-Many, T., and J. Silver. 1990. Regulation of parathyroid hormone gene expression by hypocalcemia, hypercalcemia, and vitamin $\mathrm{D}$ in the rat. $J$. Clin. Invest. 86:1313-1319.

20. Clements, M. R., L. Johnson, and D. R. Fraser. 1987. A new mechanisms for induced vitamin $\mathrm{D}$ deficiency in calcium deprivation. Nature (Lond.). 325:62-65.

21. Burgess, G. M., G. St. J. Bird, J. F. Obie, and J. W. Putney, Jr. 1991. The mechanism for synergism between phospholipase $\mathrm{C}$ - and adenylylcyclase-linked hormones in liver. J. Biol. Chem. 266:4772-4781.

22. Schatzmann, H. J. 1989. The calcium pump of the surface membrane and of the sarcoplasmic reticulum. Annu. Rev. Physiol. 51:473-485.

23. Lotersztajn, S., R. M. Epand, A. Mallat, and F. Pecker. 1984. Inhibition by glucagon of the calcium pump in liver plasma membranes. J. Biol. Chem. 259:8195-8201.

24. Randriamampita, C., and R. Y. Tsien. 1993. Emptying of intracellular $\mathrm{Ca}^{2+}$ stores releases a novel small messenger that stimulates $\mathrm{Ca}^{2+}$ influx. Nature (Lond.). 364:809-814.

25. Tanaka, H., K. A. Hruska, Y. Seino, J. D. Malone, Y. Nichii, and S. L. Teitelbaum. 1991. Dissociation of the macrophage-maturational effects of vitamin D from respiratory burst priming. J. Biol. Chem. 266:10888-10892.

26. Wali, R. K., C. L. Baum, M. D. Sitrin, and T. A. Brasitus. 1990. $1,25(\mathrm{OH})_{2}$ vitamin $\mathrm{D}_{3}$ stimulates membrane phosphoinositide turnover, activates protein kinase $\mathrm{C}$, and increases cytosolic calcium in rat colonic epithelium. $J$. Clin. Invest. 85:1296-1303.

27. Chisholm, J. C., S. Kim, and A. H. Tashjian, Jr. 1988. Modulation by 1,25-dihydroxycholecalciferol of the acute change in cytosolic free calcium induced by thyrotropin-releasing hormone in $\mathrm{GH} 4 \mathrm{Cl}$ pituitary cells. J. Clin. Invest. 81:661-668.

28. Suzuki, M., S. Kurihara, Y. Kawaguchi, and O. Sakai. 1991. Vitamin D metabolites increase $\left[\mathrm{Ca}^{2+}\right]_{i}$ in rabbit renal proximal straight the cells. $\mathrm{Am}$. J. Physiol. (Renal Fluid Electrolyte Physiol.). 260:F757-F763.

29. Glick, A. B., B. K. McCune, N. Abdulkarem, K. C. Flanders, J. A. Lumadue, J. M. Smith, and M. B. Sporn. 1991. Complex regulation of TGF $\beta$ expression by retinoic acid in the vitamin A-deficient rat. Development (Camb.). 111:1081-1086.

30. Baran, D. T., and A. M. Kelly. 1988. Lysophosphatidylinositol: A potential mediator of 1,25-dihydroxyvitamin D-induced increments in hepatocyte cytosolic calcium. Endocrinology. 122:930-934.

31. Nemere, I., Y. Yoshimoto, and A. W. Norman. 1984. Calcium transport in perfused duodena from normal chicks: Enhancement within fourteen minutes of exposure to 1,25-dihydroxyvitamin $D_{3}$. Endocrinology. 115:1476-1483.

32. Levy, R., I. Nathan, and S. Shany. 1987. 1,25-dihydroxyvitamin $D_{3}$ alters membrane phospholipid composition and enhances calcium efflux in HL-60 cells. Biochim. Biophys. Acta. 902:178-182.

33. Ways, D. K., R. C. Dodd, T. E. Bennett, T. K. Gray, and H. S. Earp. 1987. 1,25-dihydroxyvitamin $\mathrm{D}_{3}$ enhances phorbol ester-stimulated differentiation and protein kinase C-dependent substrate phosphorylation activity in the U937 human monoblastoid cell. Endocrinology. 121:1654-1661.

34. Fernandez, L. M., V. Massheimer, and A. R. De Boland. 1990. Cyclic AMP-dependent membrane protein phosphorylation and calmodulin binding are involved in the rapid stimulation of muscle calcium uptake by 1,25-dihydroxyvitamin $\mathrm{D}_{3}$. Calcif. Tissue Int. 47:314-319.

35. Bradford, P. G., Y. Jin, and P. Hui. 1993. 1,25-dihydroxyvitamin $D_{3}$ enhances the transcription and expression of the inositol trisphosphate receptor gene in HL-60 cells. Mol. Pharmacol. 44:292-297. 
36. Kruszewski, F. H., H. Hennings, S. H. Yuspa, and R. W. Tucker. 1991. Regulation of intracellular free calcium in normal murine keratinocytes. Am.J. Physiol. (Cell Physiol.). 261:C767-C773.

37. Pillai, S., G. Menon, D. Bikle, and P. M. Elias. 1993. Localization and quantitation of calcium pools and calcium binding sites in cultured human keratinocytes. J. Cell. Physiol. 154:101-112.

38. Ethier, C., D. Goupil, C. Demers, G. N. Hendy, and M. Gascon-Barré. 1993. Hypocalcemia, irrespective of the vitamin D status, decreases EGF receptor density and autophosphorylation in rat livers. Endocrinology. 133:780-792.

39. Carpenter, G., and S. Cohen. 1990. Epidermal growth factor. J. Biol. Chem. 265:7709-7712.

40. Yang, L., G. Baffy, S. G. Rhee, D. Manning, C. A. Hansen, and J. R. Williamson. 1991. Pertussis toxin-sensitive $G_{i}$ protein involvement in epidermal growth factor-induced activation of phospholipase $\mathrm{C}$-gamma in rat hepatocytes. J. Biol. Chem. 266:22451-22458.

41. Margolis, B., S. G. Rhee, S. Felder, M. Mervic, R. Lyall, A. Levitzki, A. Ullrich, A. Zilberstein, and J. Schlessinger. 1989. EGF induces tyrosine phos- phorylation of phospholipase C-II: a potential mechanism for EGF receptor signaling. Cell. 57:1101-1107.

42. Rashed, S. M., and T. B. Patel. 1991. Regulation of hepatic energy metabolism by epidermal growth factor. Eur. J. Biochem. 197:805-813.

43. Charest, R., P. F. Blackmore, B. Berthon, and J. H. Exton. 1983. Changes in free cytosolic $\mathrm{Ca}^{2+}$ in hepatocytes following $\alpha_{1}$-adrenergic stimulation. J. Biol. Chem. 258:8769-8773.

44. Chen, W. S., C. S. Lazar, M. Poenie, R. Y. Tsien, G. N. Gill, and M. G. Rosenfeld. 1987. Requirement for intrinsic protein tyrosine kinase in the immediate and late actions of the EGF receptor. Nature (Lond.). 328:820-823.

45. Woods, N. M., K. S. R. Cuthbertson, and P. H. Cobbold. 1987. Agonistinduced oscillations in cytoplasmic free calcium concentration in single rat hepatocytes. Cell Calcium. 8:79-100.

46. Kawanishi, T., L. M. Blank, A. T. Harootunian, M. T. Smith, and R. Y. Tsien. 1989. $\mathrm{Ca}^{2+}$ oscillations induced by hormonal stimulation of individual Fura-2-loaded hepatocytes. J. Biol. Chem. 264:12859-12866.

47. Gascon-Barré, M., and M. Gamache. 1991. Contribution of the biliary pathway to the homeostasis of vitamin $D_{3}$ and of 1,25-dihydroxyvitamin $D_{3}$. Endocrinology. 129:2335-2344. 